\title{
STULPMAND EN WERPNET
}

DOOR

JOH. F. SNELLEMAN

Langen tijd heb ik niets van het museum te Göteborg gehoord. Van de hoogst merkwaardige reeks „Vergleichende ethnographische Forschungen" van Erland Nordenskiöld zond hij mij geregeld de nummers met een vriendelijkheidje op het titelblad. Ziehier de serie, die van 1918 loopt tot 1930. Comparative ethnographical studies is de algemeene titel, en daarna:

1. An ethno-geographical analysis of the material culture of two Indian tribes in the Gran Chaco. 2. The changes in the material culture of two Indian tribes under the influence of new surroundings. 3. The ethnography of South-America seen from Mojos in Bolivia. 4. The copper and bronze ages in SouthAmerica. 5. Deductions suggested bij the geographical distribution of some postcolumbian words used bij the Indians of S. America. 6 (PartI) The secret of the Peruvian quipus.(Part II). Calculations with years and months in the Peruvian quipus. 7. (Part I ) Picture - writings and other documents bij Néle, Paramount chief of the Cuna Indians, and Ruben Pérez Kantule, his secretary. Part II: by Néle, Charles Slater, Charlie Nelson and other Cuna Indians. 8. Modifications in Indian culture through inventions and loans.

Het Rijksmuseum te Stockholm, Etnografiska Avdelning, zet zijn reeks Smärre Meddelanden onverdroten voort. Ziehier: 1. Einige Details in der Ornamentik der Buschneger Surinams. 2 Die Schleuder in Afrika und anderwärts. 3. The use of stilts, especially in Africa and America. 4. Fighting- bracelets and kindred weapons in Africa. The spiked wheel-trap and its distribution. 6. Further notes ou the use of stilts. 7. The use of the hammock in Africa. 8. Did prehistoric Egyptian culture spring from a Marsh-dwelling people? 9.String figures in Africa. 10. The use of oxen as pack and riding animals in Africa; hoofd- 
zakelijk van K. G. Lindblom. En dezer dagen krceg ik van Lindblom $\mathrm{n}^{\circ} 11$. Two kinds of fishing implements: $a$. The plungebasket (Stülpkorb), in Africa and elsewhere. $b$. The circular cast- net in Africa, door T. Leth en K. G. Lindblom.

De plunge- basket is wat wij de stulpmand noemen: een mandje zonder bodem dat wordt gestulpt, de grootste opening onder, over een visch die rondzwemt bij laag water; hier is bepaald bedoeld de Afrikaansche stulpmand; bijkkens de kaart wordt het voorwerp gebruikt tot den $20 \mathrm{en}$ graad N. B.; noordelijker sporadisch. De meest gebruikelijke vorm gedoogt, dat de visscher zijn hand steekt door de boven-opening en den visch grijpt. Afwijkingen worden beschreven en door afbeeldingen toegelicht.

Een afzonderlijk hoofdstuk voert naar de stulpmanden in Azië en Europa. In Azië wordt de toestel gebruikt o.a. in Soerabaya, Atjeh en de Lampongs, centraal- Celebes, Borneo, waaromtrent de catalogus van Leiden is te raadplegen. Het opstel brengt 2 afbeeldingen van Chineezen, visschende met de mand. Een slordig exemplaar uit Californië is mede afgebeeld en 2 stuks van Nieuw-Guinea. Ik herinner mij een vlieger (Museum Rotterdam) waarmede men visch vangt op Flores; het vliegertouw loopt over een katrol boven in de mast van de roeiboot, naar den visscher; aan des vliegers staart zit een lijn vast, die haak en aas draagt aan haar ondereind; door de beweging van den vlieger is de haak voortdurend in beweging aan de oppervlakte van het water. Daarin zit meer poëzie dan in een stulpmand; maar waarin zit meer visch?

En hier is de visch die zijn eigen doodsklokje luidt. In de Beneden Saramacca, en ook wel in andere rivieren, ziet men dikwijls stokken in de modder steken, waarboven een flesch of stoop is bevestigd; daarbinnen hangt een spijker aan een draad. Aan den stok is een zetlijn gebonden; komt er een visch aan de lijn, dan wordt de visscher in zijn huisje gewaarschuwd door het tingelen van den spijker tegen den fleschwand; hij behoeft niet voortdurend op de zetlijn te letten.

Het werpnet, the circular cast-net, herinner ik mij uit mijn jongenstijd, toen er in Rotterdam nog kippen liepen bij de graanpakhuizen aan de havens; thans verboden. En eveneens zal wel zijn verboden het bevisschen van de havens met het werpnet. Zulk een net heeft een radius van verscheidene meters, 12 voet vind ik opgegeven, elders $2 \frac{1}{2}$ meter, heeft kleine mazen en aan den omtrek tallooze ringetjes. De visscher, neemt een van die 
ringen tusschen, zijn lippen, draait even om zijn as en slingert, angstig dicht aan den walkant staande, met een behendigen zwaai het net van zich af. In het water zinkt het dadelijk, het eerst de omtrek met de metalen ringen; of er iets in zit blijkt eerst bij het ophalen.

In het Museu $n$ te Rotterdam vindt men een uit Java afkomstigen gietvormi voor de metalen ringen.

Den Encycl. van West-Indië (1914-17!) vermeldt ter loops (bl.717 1ste kol.) een klein werpnet, dat „soms” wordt gebruikt inSuriname. Van de eilanden vind ik genoemd het werpnet (taraai), het meest populaire en meest gebruikte net, cirkelvormig met kleine mazen uit dun garen vervaardigd en in het midden aan een touw bevestigd, en aan den omtrek met een krans van looden kogeltjes bezwaard. De diameter wisselt van 2 tot 3 meter, op behoorlijke wijze uitgeworpen, spreidt dit net zich horizontaal uit en daar de kogeltjes snel naar den bodem zinken, wordt alle visch die zich onder het net bevindt gevangen en blijft in de mazen verward als het net voorzichtig wordt opgehaald; overal op onze eilanden in gebruik, ook in veel grooter afmetingen, met wijdere mazen voor het vangen van schildpadden (taraai di toertocca). Aldus prof. J. Boeke in zijn Encyclopaedie-artikel: Visscherijbedrijf op de Ned. W.I. Eilanden (719).

In den catalogus van de Amsterdamsche tentoonstelling van 1883 vond ik (groep I, 6de klasse) een ,,verzameling van Surinaam sche visschen nagebootst door galvanoplastiek". Inzender was M. R. Matthes ,in Suriname”. N.B. (en de waarschuwing is gepast) „de namen waardoor deze visschen zijn aangeduid, zijn meestal de Neger-Engelsche. De determinatie laat veel te wenschen over en vele geslachts- en soortnamen zijn door den afschrijver misvormd. De vraagteekens achter de Latijnsche namen zijn van den inzender, die vóór de Latijnsche namen duiden aan, dat deze zoo misvormd waren, dat de poging tot verbetering zeer onzeker is".

Toen in 1928 te Arnhem een tentoonstelling is ingericht met o.a. een West-Indische afdeeling heb ik daarover geschreven in de October-aflevering van dezen Gids, bl. 275; aan het slot de opmerking, dat ik er veel belangrijks had gevonden. Zij die er waren zullen zich herinneren den ",zeetuin". Wonderlijker toestel heb ik nooit aanschouwd: al die heen en weer schommelende visschen en andere gedierten waren rechtaf vermakelijk. Was het dezelfde collectie die in 1883 te Amsterdam prijkte, ,nagebootst door galvanoplastiek"?

Van Musschenbroek beweerde in '83 (Inleiding groep II 10de 
klasse), dat er in West-Indië veel visch is te rinden, „doch de visscherij zelve, op Curaçao eenigszins meer ontwikkeld is in Suriname nog achterlijk". De stulpmand noemt hij (bl. 109) een ,toestelletje” "geheel aan Indië alleen eigen". We weten nu beter; maar of deze toestel ook in ons land wordt gebruikt, heb ik niet kunnen vinden.

Hoe oud is het werpnet? heb ik gevraagd. Keth en Lindblom schrijven in hun opstel "Two kinds of fishing implements", bl. 45: "Its earliest employment in Africa was supposedly in Egypt, notwithstanding that only sparse illustrations of them are found from ancient Egyptian times. In our days they are used on the Nile by Arabs, and the same is the case on the shores of the Red Sea, the Palestine, and in Syria". Nu lag het toch voor de hand den Bijbel erop na te slaan in voce Visscherij. Hier is Mattheus $4: 18$ waar we ontmoeten "Simon, geseght Petrus, ende Andreas synen broeder, het net in de zee werpende (want sy waren visschers)." In een noot lezen we: „Deze zee was een groot binnenlandsch meir. Want de Hebreeuwen noemen alle grote vergaderingen van water zeën." En bij het woord net de annotatie, „Gr. werpnet." Verder lezen we over een net geworpen in de zee in Mattheus $13: 47$, in Lukas $5: 4$ en volgende, zoo ook Johannes $21: 6$ en volgende.

Hier is telkens het werpnet in actie; geen ander net werpt men in het water. Het kruisnet, de totebel, laat men zachtjes in het water dalen door de lijn te vieren waaraan het net is vastgemaakt. Er wordt mede gevischt op de pier van Scheveningen; een behendigheids-spel is 't geenszins, veeleer een nogal saai nummer in de rubriek vischvangst.

Een andere manier van visschen wordt in het Nieuwe Testament anders omschreven; in Matth. 18:27 lezen we: ,gaet henen na de zeen, werpt den angel (uyt) ende den eersten visch die opkomt" enz.

Voor de aanwijzing van mededeelingen betreffende het werpnet houd ik mij aanbevolen. Maar zij moeten ouder zijn dan het jaar nul. 